\title{
Effect of cooking methods on nutritional composition and antioxidant properties of lotus (Nelumbo nucifera) rhizome
}

\author{
${ }^{1}$ Chen, S.Y. and ${ }^{1,2 *}$ Tengku Rozaina, T.M. \\ ${ }^{1}$ Faculty of Fisheries and Food Science, Universiti Malaysia Terengganu, 21030 Kuala Nerus, Terengganu, \\ Malaysia \\ ${ }^{2}$ Institute of Tropical Biodiversity and Sustainable Development, Universiti Malaysia Terengganu, 21030, \\ Kuala Nerus, Terengganu, Malaysia
}

\begin{abstract}
Article history:
Received: 28 October 2019

Received in revised form: 18

February 2020

Accepted: 20 February 2020

Available Online: 11 April 2020
\end{abstract}

Keywords:

Lotus rhizome,

Proximate composition,

Minerals,

Vitamin C,

Antioxidant,

Cooking methods

DOI:

https://doi.org/10.26656/fr.2017.4(4).359

\section{Introduction}

Lotus (Nelumbo nucifera) in the Nelumbonaceae family is an aquatic plant widely grown in Asian countries such as China, Japan and India. It is cultivated for food, ornamental and medicinal purpose (Zhao et al., 2016). According to Wang (2014), lotus rhizome is rich in starch, sugars, lipids, proteins, minerals, vitamins, alkaloids, flavonoids and other biochemical substances. It contains alkaloids that is used in treating arrhythmia, sunstroke, fever, diarrhoea, dysentery, dizziness and stomach problems (Shad et al., 2011). Furthermore, it also has pharmacological activities such as antidiarrhoeal, anti-inflammatory, antioxidant, antipyretic, diuretic, hypoglycaemic, immunomodulatory and psychopharmacological activities (Bhardwaj and Modi, 2016; Yi et al., 2016). The extract of lotus rhizome especially from its nodes contains a high amount of antioxidant such as phenolic, tannin and flavonoid
(Moro, 2012).

Lotus rhizome has potential to be cultivated widely as another important crop in Malaysia, just like sweet potato or cocoyam, as it can be harvested year-round and can be grown in an environment which is unfavourable for other traditional agricultural crops. However, the production of lotus in Malaysia is limited due to the low market demand compared to other vegetables. The consumption of lotus rhizome in Malaysia is limited to Chinese and Indian population. The Malay population in Malaysia rarely consumes the lotus rhizome since not much information on the nutritional value of it is available. The popularity of lotus rhizome is mainly due to its attractiveness white colour and the crispness texture ( $\mathrm{Li}$ et al., 2017). The fresh lotus rhizome is popular to be sliced and deep-fried as chips for snacks. This is because deep-frying creates unique texture, flavour and taste for the food (Oke et al., 2017). 
According to Metha (2015), vegetables are cooked before consumption to improve their palatability, aroma, taste, appearance, and texture to achieve high acceptance among consumers. Cooking or processing method caused nutrients loss in food product and the amount of loss was depended on the method used. The heat applied during cooking caused the nutrients, which were sensitive to heat, light, oxygen and $\mathrm{pH}$, to be unstable and lead to their thermal degradation (Omotosho et al., 2016).

Most consumers eat lotus rhizome because of its mild sweet flavour or as a part of their traditional food habit without knowing the nutritional value of lotus rhizome. There is a lack of research done purposely to investigate the effect of different cooking methods on the nutritional composition and antioxidant properties of lotus rhizome. Li et al. (2017) focused on the effect of steaming and boiling on the physicochemical properties of lotus (Nelumbo nucifera) root, such as moisture content, texture and volatile compounds (methylcyclohexance and ethylcyclohexance). Another study conducted by Zhao et al. (2016) investigated the effect of heat blanching and calcium immersion on physicochemical properties related to the texture of rhizome. Meanwhile, Vora and Srinivasan (2015) studied on the nutritional benefits of raw and fried lotus stems. Frying caused the reduction of iron, calcium, phosphorus, sodium and vitamin $\mathrm{C}$ content and increased the amount of carbohydrate, protein and dietary fibre in lotus stem (Vora and Srinivasan, 2015).

The objectives of this study are to determine the effect of cooking methods on the proximate composition, vitamin $\mathrm{C}$, minerals content, and antioxidant properties of lotus (Nelumbo nucifera) rhizome. Information obtained from this study would be beneficial to consumers in choosing the good cooking method for lotus rhizome and is expected to encourage its consumption among various communities in Malaysia.

\section{Materials and methods}

\subsection{Sample preparation and cooking treatments}

Five (5) $\mathrm{kg}$ of lotus (Nelumbo nucifera) rhizomes with an average length of $45.0-57.0 \mathrm{~cm}$ and width of 4.0$5.0 \mathrm{~cm}$ were purchased from the farmer at Ipoh, Perak. The samples were washed, peeled and sliced into $0.3 \mathrm{~cm}$ of thickness. The lotus rhizome slices were divided into four portions, where one portion was left as raw for control while the other three portions were cooked by steaming, boiling and deep-frying. The cooking conditions were as follows:
Steaming: Lotus rhizome slices $(0.9 \mathrm{~kg})$ were steamed for 30 mins in $3 \mathrm{~L}$ of $100^{\circ} \mathrm{C}$ boiling water in a steamer until they were tender.

Boiling: Lotus rhizome slices $(0.9 \mathrm{~kg})$ were boiled for 30 mins in $2 \mathrm{~L}$ of $100^{\circ} \mathrm{C}$ boiling water in a stock pot until they were tender.

Deep frying: Lotus rhizome slices $(0.9 \mathrm{~kg})$ were deep -fried for 1.5 mins in a saucepan with $350 \mathrm{~mL}$ palm oil (Bagus, Sime Darby Plantation, Malaysia) at $170 \pm 2.0^{\circ} \mathrm{C}$ until they were crispy.

All samples were cooked without adding any salt or additional ingredients. The cooked samples were taken for quick freezing in a blast freezer (Technomac, Malaysia) at $-20^{\circ} \mathrm{C}$ for two hrs and stored in a freezer (Panasonic, Malaysia) at $-20^{\circ} \mathrm{C}$ before further analysis.

\subsection{Proximate analysis}

Proximate analysis of lotus rhizome was carried out according to AOAC (2005) methods. The samples were dried in an oven (Chemopharm, Malaysia) at $105^{\circ} \mathrm{C}$ for overnight for moisture determination. Analysis of ash was carried out by heating the samples in a muffle furnace (Carbolite, Malaysia) at $550^{\circ} \mathrm{C}$ for overnight. Crude fat content was analysed using Labtec ST310 (Foss, Malaysia) with petroleum ether (EMSURE, Germany) as extraction solvent. Crude protein content was measured using a Kjeldahl method with Turbotherm digestion unit (Gerhardt, Malaysia) and Vapodest 30S distillation unit (Gerhardt, Malaysia). The conversion factor for nitrogen-protein percentage used was 6.25. The samples were boiled with $0.13 \mathrm{M} \mathrm{H}_{2} \mathrm{SO}_{4}(\mathrm{R} \& \mathrm{M}$ Chemical, Malaysia) and $0.31 \mathrm{M} N \mathrm{NaOH}$ (R\&M Chemical, Malaysia) in Gerhardt Fibre Bag system for determination of crude fibre content. The carbohydrate content of the sample was calculated by subtracting $100 \%$ with the sum of percentage of moisture, ash, crude fat, crude protein and crude fibre contents.

\subsubsection{Oil uptake and moisture loss}

The oil uptake and moisture loss of deep-fried lotus rhizome were determined according to Kim et al. (2015) method and calculated as follows:

$$
\begin{gathered}
\text { Oil uptake }(\%)=\frac{\mathrm{W}_{\mathrm{D}} \times \mathrm{F}_{\mathrm{D}}-\mathrm{W}_{\mathrm{d}} \times \mathrm{F}_{\mathrm{d}}}{\mathrm{W}_{\mathrm{D}}} \times 100 \\
\text { Moisture loss (\%) }=\frac{\mathrm{W}_{\mathrm{d}} \times \mathrm{M}_{\mathrm{d}}-\mathrm{W}_{\mathrm{D}} \times \mathrm{M}_{\mathrm{D}}}{\mathrm{W}_{\mathrm{D}}} \times 100
\end{gathered}
$$

Where $\mathrm{W}_{\mathrm{D}}=$ mass of cooked sample $(\mathrm{g}) ; \mathrm{W}_{\mathrm{d}}=$ mass of raw sample $(\mathrm{g}) ; \mathrm{F}_{\mathrm{D}}=$ fat amount of cooked sample $(\mathrm{g} / \mathrm{g}$ wet basic); $F_{d}=$ fat amount of raw sample $(\mathrm{g} / \mathrm{lg}$ wet basic); $\mathrm{M}_{\mathrm{D}}=$ moisture content of cooked sample $(\mathrm{g} / \mathrm{g}$ 
wet basic); and $\mathrm{M}_{\mathrm{d}}=$ moisture content of raw sample (g/1g wet basic).

\subsection{Vitamin $C$ analysis}

Lotus rhizome juice was prepared by grounding $10 \mathrm{~g}$ of chopped lotus rhizome slices with $50 \mathrm{~mL}$ distilled water (Hussain et al., 2016). The mixture was filtered and added with 3\% metaphosphoric acid (EMSURE, Germany) until the volume became $100 \mathrm{~mL}$. Determination of vitamin $\mathrm{C}$ was carried out according to Pegg et al. (2010) method. Lotus rhizome juice (10 mL) was titrated with 2,6-Dichlorophenolindophenol (DCPIP) dye solution until pink colour exists for $15 \mathrm{~s}$. The ascorbic acid content was calculated using the formula below:

$$
\text { Ascorbic acid content }(\mathrm{mg} / 100 \mathrm{~g})=(\mathrm{X}-\mathrm{B}) \times\left(\frac{0.0543}{10}\right) \times\left(\frac{100}{10}\right)
$$

Where $\mathrm{X}=$ volume for test solution titration $(\mathrm{mL})$ and $\mathrm{B}$ $=$ volume for test blank titration $(\mathrm{mL})$.

\subsection{Mineral analysis}

Mineral extraction of lotus rhizome samples was carried out according to AOAC (2005) method. Lotus rhizome $(1.5 \mathrm{~g})$ was incinerated in a muffle furnace to form ash to be evaporated to dryness on a hot plate (Favorit, Malaysia) with $2 \mathrm{~mL}$ of concentrated $\mathrm{HCl}$ (EMSURE, Malaysia). Subsequently, $10 \mathrm{~mL}$ of $20 \%$ concentrated $\mathrm{HNO}_{3}$ (Merck, Germany) was added. After incubation in water bath at $60^{\circ} \mathrm{C}$ for 1 hour, the mixture was diluted into $100 \mathrm{~mL}$ with distilled water and filtered using Whatman No.42 filter paper prior to analysis. Determination of mineral content of lotus rhizome was carried out using Inductively Coupled Plasma-Optical Emission Spectrometry (ICP-OES) (Optima 8300, PerkinElmer, USA) according to Akpinar-Bayizit et al. (2010) method.

\subsection{Antioxidant analysis}

\subsubsection{Antioxidant extraction}

Antioxidant extraction of lotus rhizome slices was carried out according to Leong et al. (2012) method. Chopped lotus rhizome samples were dried in an oven (Southstar, Malaysia) at $50^{\circ} \mathrm{C}$ for $48 \mathrm{hrs}$ until almost 5$7 \%$ moisture content left. They were grounded to pass a $1 \mathrm{~mm}$ sieve. Lotus rhizome powder $(5.0 \mathrm{~g})$ was mixed with $50 \mathrm{~mL}$ of methanol (EMSURE, Germany) for overnight incubation in darkness at room temperature $\left(28^{\circ} \mathrm{C}\right)$. The mixture was centrifuged (Hettich Zentrifugen, Malaysia) at $3000 \mathrm{r} / \mathrm{min}$ for $15 \mathrm{mins}$. The supernatant was separated through filtration with Whatman No.1 filter paper and was evaporated at $40^{\circ} \mathrm{C}$ using a rotary evaporator (Buchi, Malaysia). The yield of antioxidant extraction of lotus rhizome was calculated using the following equation:

$$
\text { Yield }(\%)=\frac{\text { Weight of dry extract }(\mathrm{g})}{\text { Weight of lotus rhizome powder }(\mathrm{g})} \times 100 \%
$$

\subsubsection{Total phenolic content (TPC)}

Total phenolic content (TPC) in lotus rhizome was determined using the Folin Ciocalteu method according to Zhao et al. (2014). Lotus rhizome extract solution of $0.1 \mathrm{~mL}$ of $5 \mathrm{mg} / \mathrm{mL}$ was mixed with $2 \mathrm{~mL}$ distilled water and $1 \mathrm{~mL}$ of Folin Ciocalteu phenol reagent (R\&M Chemical, Malaysia) for incubation in darkness at room temperature $\left(28^{\circ} \mathrm{C}\right)$ for 5 mins. A total of $5 \mathrm{~mL}$ of $20 \%$ aqueous $\mathrm{Na}_{2} \mathrm{CO}_{3}$ solution (Bendosen, Malaysia) was added followed by incubation for $60 \mathrm{mins}$. The absorbance was measured at $735 \mathrm{~nm}$ using UV-Vis spectrophotometer (Interscience, Malaysia) with distilled water as blank. Gallic acid (R\&M Chemical, Malaysia) was used as standard. TPC (GAE/g DE) in lotus rhizome was calculated through a linear regression equation obtained from gallic acid standard graph.

\subsubsection{Total flavonoid content (TFC)}

Aluminium chloride coloration method was adopted for the estimation of total flavonoid content (TFC) in lotus rhizome according to Zhao et al. (2014). Lotus rhizome extract solution of $0.6 \mathrm{~mL}$ of $10 \mathrm{mg} / \mathrm{mL}$ was mixed with $3.75 \mathrm{~mL}$ distilled water and $0.225 \mathrm{~mL}$ of $5 \%$ aqueous $\mathrm{NaNO}_{3}$ solution for incubation in darkness at room temperature $\left(28^{\circ} \mathrm{C}\right)$ for 6 mins. A total of $0.45 \mathrm{~mL}$ $10 \% \mathrm{AlCl}_{3}$ solution (Sigma-Aldrich, USA), $1.5 \mathrm{~mL}$ of 1 $\mathrm{mol} / \mathrm{mL} \mathrm{NaOH}$ solution (R\&M Chemical, Malaysia) and $0.975 \mathrm{~mL}$ of distilled water were added to the mixture before incubation for 15 mins. The absorbance was measured at $500 \mathrm{~nm}$ using UV-Vis spectrophotometer (Interscience, Malaysia) with distilled water as blank and catechin (TGI, Tokyo) as standard. TFC (CE/g DE) in lotus rhizome was calculated through a linear regression equation obtained from catechin standard graph.

\subsubsection{DPPH radical scavenging activity}

DPPH radical scavenging activity of lotus rhizome extract was measured as in accordance to Zhao et al. (2014) with slight modification. A series of lotus rhizome extract solution $(0.5$ to $3.0 \mathrm{mg} / \mathrm{mL})$ was mixed with $5 \mathrm{~mL}$ of $0.1 \mu \mathrm{mol} / \mathrm{L} \mathrm{2,} \mathrm{2-diphenyl-1-picrylhydrazyl}$ (DPPH; Sigma-Aldrich, Germany) solution in methanol for incubation in darkness at room temperature for 30 mins. The absorbance was measured at $517 \mathrm{~nm}$ using UV -Vis spectrophotometer (Interscience, Malaysia) with methanol as blank. The following equation was used for the calculation of DPPH free radical scavenging activity: 
Scavenging ability $(\%)=\left(\frac{A_{\text {control }}-A_{\text {sample }}}{A_{\text {control }}}\right) \times 100 \%$

Where $\mathrm{A}_{\text {control }}=$ absorbance of the control and $\mathrm{A}_{\text {sample }}=$ absorbance of the sample

A graph of scavenging ability against the concentration of the sample extract was plotted to determine the amount of lotus rhizome extract with $50 \%$ scavenging activity $\left(\mathrm{IC}_{50}\right)$ values.

\subsubsection{ABTS radical scavenging activity}

Analysis of 2,2'-azino-bis(3-ethylbenzothiazoline-6sulfonic acid) (ABTS) radical scavenging activity of lotus rhizome extract was conducted using $\mathrm{Wu}$ et al. (2011) method. ABTS $^{+}$radical solution was prepared by incubating the mixture of $3 \mathrm{~mL}$ of $7 \mathrm{mM}$ ABTS stock solution (Sigma-Aldrich, USA) and $3 \mathrm{~mL}$ of $2.45 \mathrm{mM}$ potassium persulfate (EMSURE, Germany) at room temperature for $16 \mathrm{hrs}$ in darkness. The mixture was diluted with $80 \%$ ethanol (HmbG Chemical, Malaysia) to obtain absorbance of $0.70 \pm 0.005$ at $734 \mathrm{~nm}$ using UVVis spectrophotometer (Interscience, Malaysia). A total of $0.3 \mathrm{~mL}$ of a series of lotus rhizome extract solution $(0.5$ to $3.0 \mathrm{mg} / \mathrm{mL})$ was mixed with $2.7 \mathrm{~mL}$ of $\mathrm{ABTS}^{+}$ radical solution and incubated for 30 mins. The absorbance was measured at $734 \mathrm{~nm}$ using UV-Vis spectrophotometer with methanol as blank. The scavenging ability (\%) and $\mathrm{IC}_{50}$ values were determined as previously described for DPPH.

\subsection{Statistical analysis}

All analyses were carried out in the triplicate and data was expressed in mean \pm standard deviation form. Statistical analysis was carried out using one-way ANOVA and Tukey's-b using SPSS version 16 (SPSS Inc., USA).

\section{Results and discussion}

\subsection{Proximate composition}

Table 1 shows the raw lotus rhizome contained $86.86 \%$ moisture, $1.05 \%$ ash, $0.14 \%$ crude fat, $2.34 \%$ crude protein, $0.80 \%$ crude fibre and $8.81 \%$ carbohydrate. This finding is in accordance with Wang (2014) findings on lotus rhizome samples. Meanwhile,
Read (1982) reported that lotus rhizome contained 1.70\% protein, $0.10 \%$ fat, $9.7 \%$ carbohydrate and $1.10 \%$ ash. The variation in the proximate composition of lotus rhizomes in the present and previous studies may be due to differences in the maturity level and planting location of lotus rhizome samples. This finding is supported by Agunbiade et al. (2017) and Chinomso et al. (2018) on orange-fleshed sweet potato and on Moringa oleifera leaves in their studies, respectively.

The moisture content of steamed $(89.20 \%)$ and boiled lotus rhizome $(91.51 \%)$ was significantly different with raw $(86.86 \%)$ lotus rhizome $(\mathrm{p}<0.05)$. A similar result was reported by Bembem and Sadana (2013) and Okibe et al. (2016) where the moisture content of their potato and pumpkin leaves were higher after boiled, respectively. According to Lola (2009), fibre and other chemical compounds presented in the vegetables absorbed water during boiling.

In this study, the moisture content of the deep-fried lotus rhizome was lowest (15.37\%) compared to raw and other cooked lotus rhizomes. This finding is in agreement with Shunmugapriya and Kalaiselvan (2017) who reported that fried garlic possessed the lowest percentage of moisture content compared to steamed and boiled samples. The high heat applied during deep-frying caused the moisture escaped from food through evaporation (Omotosho et al., 2016; Oke et al., 2017). On the other hand, the ash content of deep-fried sample was the highest $(3.71 \%)$, followed by raw $(1.05 \%)$, steamed $(0.69 \%)$ and boiled sample $(0.17 \%)$. Boiling might reduce more ash content than steaming due to the leaching out of mineral into boiling water (Lola, 2009; Wang et al., 2012). The ash increment occurred in deepfried samples was related to the moisture lost. Dehydration concentrated the nutrient left in the sample and thus increased the ash content in the fried product (Yodkraisri and Bhat, 2012).

There was no significant difference $(\mathrm{p}>0.05)$ found between crude fat content of raw and steamed $(0.11 \%)$ samples and between crude fat content of raw and boiled $(0.06 \%)$ lotus rhizome (Table 1$)$. A similar result was reported by Hwang et al. (2012) on red pepper. A large increase of crude fat content was found on the deep-fried lotus rhizome in the present study and this is in

Table 1. Proximate composition on a wet weight basis for raw and cooked lotus rhizomes

\begin{tabular}{lcccccc}
\hline \multirow{2}{*}{ Lotus rhizome } & \multicolumn{5}{c}{ Proximate composition } \\
\cline { 2 - 7 } & Moisture (\%) & Ash (\%) & Crude fat (\%) & Crude protein (\%) & Crude fibre (\%) & Carbohydrate (\%) \\
\hline Raw & $86.86 \pm 0.35^{\mathrm{c}}$ & $1.05 \pm 0.05^{\mathrm{b}}$ & $0.14 \pm 0.01^{\mathrm{b}}$ & $2.34 \pm 0.17^{\mathrm{b}}$ & $0.80 \pm 0.02^{\mathrm{c}}$ & $8.81 \pm 0.51^{\mathrm{b}}$ \\
Steamed & $89.20 \pm 0.25^{\mathrm{b}}$ & $0.69 \pm 0.08^{\mathrm{c}}$ & $0.11 \pm 0.01^{\mathrm{b}}$ & $2.22 \pm 0.12^{\mathrm{b}}$ & $1.01 \pm 0.06^{\mathrm{c}}$ & $6.76 \pm 0.46^{\mathrm{b}}$ \\
Boiled & $91.51 \pm 0.53^{\mathrm{a}}$ & $0.17 \pm 0.01^{\mathrm{d}}$ & $0.06 \pm 0.01^{\mathrm{b}}$ & $0.77 \pm 0.05^{\mathrm{c}}$ & $2.06 \pm 0.07^{\mathrm{b}}$ & $5.43 \pm 0.46^{\mathrm{b}}$ \\
Deep fried & $15.37 \pm 1.90^{\mathrm{d}}$ & $3.71 \pm 0.25^{\mathrm{a}}$ & $31.41 \pm 1.07^{\mathrm{a}}$ & $8.33 \pm 0.38^{\mathrm{a}}$ & $12.28 \pm 0.20^{\mathrm{a}}$ & $28.91 \pm 2.67^{\mathrm{a}}$ \\
\hline
\end{tabular}

Mean $\pm \mathrm{SD}, \mathrm{n}=3$. Values with different superscript letters in the same column are significantly different at $\mathrm{p}<0.05$ 
accordance with Omotosho et al. (2016) on unripe plantain. Deep-fried food increased its fat content through extra fat absorption from the frying oil and decreased its moisture content through moisture escaping from food due to high heat (Bordin et al., 2013).

The moisture loss and oil uptake of deep-fried lotus rhizome were $73.88 \%$ and $31.27 \%$, respectively. This finding is in agreement with Manjunatha et al. (2012) on Gethi (Dioscorea kammonensis kunths) strips. According to Kita (2014), moisture loss would cause dehydration which contributed to changes in cell structure and formation of small channel matrix occupied subsequently by the frying oil. Vigorous water escaped from vegetable had limited the oil absorption during the frying process, causing a higher rate of moisture loss than oil uptake (Bouchon et al., 2003).

The highest crude protein content was found on deep -fried $(8.33 \%)$ lotus rhizome followed by raw $(2.34 \%)$, steamed $(2.22 \%)$ and boiled $(0.77 \%)$ lotus rhizome. The large increment in crude protein content of deep-fried food was contributed by the moisture loss which concentrated the organic materials left (Vora and Srinivasan, 2015) and by the hydrolysis of insoluble protein compound which increased the protein availability (Reid et al., 2016). Meanwhile, boiling decreased crude protein content of lotus rhizome, which is in accordance with the previous studies on potato (Bembem and Sadana, 2013) and red pepper (Hwang et al., 2012). Soluble nitrogenous substance leached out into boiled water when cooked, causing more loss rather than denaturation (Reid et al., 2016).

Deep frying increased the crude fibre content of lotus rhizome from $0.80 \%$ to $12.28 \%$. Similar results were observed on four varieties of potato (Murniece et al., 2011), lotus stem (Vora and Srinivasan, 2015) and purple flesh potatoes (Tian et al., 2016). This is probably due to structural damage to the cells, which induced a marked loss of other liposoluble compounds and increased fibre content (Sun et al., 2014). Furthermore, the increase in fibre content in cooked samples were due to dehydration because of moisture loss (Vora and
Srinivasan, 2015). The highest carbohydrate content was also found in the deep-fried lotus rhizome, followed by steamed, raw and boiled lotus rhizome.

\subsection{Vitamin $C$ content}

Table 2 shows the amount of vitamin $\mathrm{C}$ and minerals in the raw and cooked lotus rhizomes in the present study. The raw lotus rhizome contained $15.02 \mathrm{mg} / 100 \mathrm{~g}$ vitamin $\mathrm{C}$. This amount was higher than the vitamin $\mathrm{C}$ in the lotus (Nelumbo nucifera) rhizomes reported by Shad et al. $(2011 ; 0.26-0.35 \mathrm{mg} / \mathrm{g})$ but lower than USDA $(2016 ; 44 \mathrm{mg} / 100 \mathrm{~g})$. The differences probably due to cultural practice, maturity, preharvest climatic conditions, harvesting method influenced the vitamin $\mathrm{C}$ level in vegetables as stated by Lee and Kader (2000) and Duya (2017).

Boiling and deep-frying significantly decreased the vitamin $\mathrm{C}$ content in lotus rhizome. The amount of vitamin $\mathrm{C}$ in the boiled and deep-fried lotus rhizomes in the present study were $3.80 \mathrm{mg} / 100 \mathrm{~g}$ and $1.45 \mathrm{mg} / 100$ $\mathrm{g}$, respectively. This finding is in contrast with Ikanone and Oyekan (2014) who reported that boiled Irish potato and sweet potato lost more vitamin $\mathrm{C}$ than the fried samples. Meanwhile, previous studies showed that the steaming cooking method retained more vitamin $\mathrm{C}$ in potato tubers (Bembem and Sadana, 2013), and broccoli, spinach and lettuce (Zeng, 2013) compared to the boiling method. This probably due to vitamin $\mathrm{C}$ is a heatsensitive water-soluble nutrient as reported by Igwemmar et al. (2013).

Apart from thermal degradation, vitamin $\mathrm{C}$ would be lost through leaching out during boiling (Yuan et al., 2009). Thus, boiling contributed to the highest reduction of vitamin C content for lotus rhizome compared to deep frying as it caused both thermal degradation and leaching out of vitamin C. Moreover, oxidation of vitamin C occurred easily in aqueous solution and could be enhanced by higher temperature, physical damage and relative humidity (Lee and Kader, 2000). In the deepfried sample, the loss of vitamin $\mathrm{C}$ was due to the higher temperature $\left(170^{\circ} \mathrm{C}\right)$ applied during frying. The rate of vitamin $\mathrm{C}$ retention in cooked food was influenced by

Table 2. Vitamin C and mineral composition of raw and cooked lotus (Nelumbo nucifera) rhizome.

\begin{tabular}{ccccccccccc}
\hline \multirow{2}{*}{$\begin{array}{c}\text { Lotus } \\
\text { rhizome }\end{array}$} & $\begin{array}{c}\text { Vitamin C } \\
(\mathrm{mg} / 100 \mathrm{~g})\end{array}$ & $\mathrm{K}$ & $\mathrm{Ca}$ & $\mathrm{Mg}$ & $\mathrm{Fe}$ & $\mathrm{Zn}$ & $\mathrm{Cu}$ & $\mathrm{Mn}$ & $\mathrm{Na}$ & $\mathrm{P}$ \\
\cline { 3 - 10 } & 15.02 & 2437.53 & 151.75 & 134.61 & 13.27 & 5.08 & 2.64 & 1.49 & 74.14 & 804.63 \\
\multirow{2}{*}{ Raw } & $\pm 1.36^{\mathrm{a}}$ & $\pm 37.95^{\mathrm{a}}$ & $\pm 1.76^{\mathrm{c}}$ & $\pm 1.34^{\mathrm{b}}$ & $\pm 0.32^{\mathrm{b}}$ & $\pm 0.07^{\mathrm{a}}$ & $\pm 0.05^{\mathrm{a}}$ & $\pm 0.02^{\mathrm{b}}$ & $\pm 0.89^{\mathrm{b}}$ & $\pm 5.63^{\mathrm{b}}$ \\
& 13.40 & 2512.60 & 201.20 & 148.89 & 24.34 & 5.55 & 2.96 & 2.57 & 76.97 & 914.58 \\
Steamed & $\pm 1.14^{\mathrm{a}}$ & $\pm 37.06^{\mathrm{a}}$ & $\pm 1.67^{\mathrm{b}}$ & $\pm 1.31^{\mathrm{a}}$ & $\pm 1.37^{\mathrm{a}}$ & $\pm 0.45^{\mathrm{a}}$ & $\pm 0.45^{\mathrm{a}}$ & $\pm 0.03^{\mathrm{a}}$ & $\pm 1.27^{\mathrm{a}}$ & $\pm 3.29^{\mathrm{a}}$ \\
& 1.45 & 617.30 & 263.27 & 113.95 & 12.02 & $3.52^{2}$ & 1.61 & 2.61 & 43.70 & 376.50 \\
Boiled & $\pm 0.31^{\mathrm{b}}$ & $\pm 8.18^{\mathrm{c}}$ & $\pm 1.49^{\mathrm{a}}$ & $\pm 0.61^{\mathrm{c}}$ & $\pm 0.55^{\mathrm{b}}$ & $\pm 0.03^{\mathrm{b}}$ & $\pm 0.01^{\mathrm{b}}$ & $\pm 0.03^{\mathrm{a}}$ & $\pm 0.71^{\mathrm{d}}$ & $\pm 2.04^{\mathrm{d}}$ \\
& 3.80 & 1481.53 & 92.06 & 69.19 & 7.27 & 2.53 & 1.29 & 1.09 & 52.12 & 442.28 \\
\multirow{2}{*}{ Deep fried } & $\pm 0.54^{\mathrm{b}}$ & $\pm 29.92^{\mathrm{b}}$ & $\pm 1.92^{\mathrm{d}}$ & $\pm 1.07^{\mathrm{d}}$ & $\pm 0.73^{\mathrm{c}}$ & $\pm 0.27^{\mathrm{c}}$ & $\pm 0.01^{\mathrm{b}}$ & $\pm 0.01^{\mathrm{c}}$ & $\pm 0.57^{\mathrm{c}}$ & $\pm 4.52^{\mathrm{c}}$ \\
\hline
\end{tabular}

Mean $\pm \mathrm{SD}, \mathrm{n}=3$. Values with different superscript letters in the same column are significantly different at $\mathrm{p}<0.05$ 
the size of cut, use of cooking media, time and temperature of cooking (Severi et al., 1997).

\subsection{Mineral composition}

Raw lotus rhizome was composed of potassium $(2437.53 \mathrm{mg} / 100 \mathrm{~g})$, calcium $(151.75 \mathrm{mg} / 100 \mathrm{~g})$, iron $(13.27 \mathrm{mg} / 100 \mathrm{~g})$, zinc $(5.08 \mathrm{mg} / 100 \mathrm{~g})$, copper $(2.64$ $\mathrm{mg} / 100 \mathrm{~g})$, manganese $(1.49 \mathrm{mg} / 100 \mathrm{~g})$, sodium $(74.14$ $\mathrm{mg} / 100 \mathrm{~g})$, and phosphorus $(804.63 \mathrm{mg} / 100 \mathrm{~g})$ as shown in Table 2. These findings were contradicted with USDA (2016) which reported that there were about $556 \mathrm{mg}$ potassium $(\mathrm{K}), 45 \mathrm{mg}$ calcium $(\mathrm{Ca}), 1.16 \mathrm{mg}$ iron $(\mathrm{Fe})$, $0.39 \mathrm{mg}$ zinc $(\mathrm{Zn}), 0.26 \mathrm{mg}$ copper $(\mathrm{Cu}), 0.26 \mathrm{mg}$ manganese $(\mathrm{Mn}), 40 \mathrm{mg}$ sodium $(\mathrm{Na})$ and $100 \mathrm{mg}$ phosphorus (P) presented in lotus rhizome. Jongrungruangchok et al. (2010) stated that the minerals of Moringa oleifera leaves obtained from different regions in Thailand varied in mineral content because of several reasons such as cultivated regions, growing conditions, nature of soil, seasonal changes, genetically different cultivars and storage conditions. Pongrac et al. (2016) also found that the amounts of mineral compounds for grains and sprouts were different from each other when they were cultivated in tap water or moderately mineral-rich water.

Three types of trend were observed for the mineral content in lotus rhizomes in the present study. The trends were steamed $>$ raw $>$ deep-fried $>$ boiled for K, Na and $\mathrm{P}$; steamed $>$ raw $>$ boiled $>$ deep-fried for $\mathrm{Mg}, \mathrm{Fe}, \mathrm{Zn}$ and $\mathrm{Cu}$; and boiled $>$ steamed $>$ raw $>$ deep-fried for $\mathrm{Ca}$ and Mn. According to Ikanone and Oyekan (2014), boiling caused a higher loss of $\mathrm{Zn}, \mathrm{Mg}, \mathrm{Na}$ and $\mathrm{Ca}$ and lower loss of $\mathrm{Cu}$ and $\mathrm{Fe}$ for Irish and sweet potato compared to frying. Contrastingly, boiling caused more loss for $\mathrm{Na}$ and $\mathrm{Ca}$ but not for $\mathrm{Zn}$ and $\mathrm{Mg}$ compared to frying in the lotus rhizome in the present study. Vora and Srinivasan (2015) reported that frying reduced $\mathrm{Na}$ and $\mathrm{Fe}$ in lotus stem whereas Okibe et al. (2016) reported that steaming retained $\mathrm{K}, \mathrm{Na}, \mathrm{Ca}, \mathrm{Mg}, \mathrm{Fe}$ and $\mathrm{P}$ better than boiling as minerals were soluble in water and could leach out into boiling medium during cooking (Okibe et al., 2016). The findings in Vora and Srinivasan (2015) and Okibe et al. (2016) were in accordance with the present study.
Generally, different type of mineral would undergo different rate of losses even though they were treated with the same cooking method. This condition was contributed by different proportion of soluble salt, which leach out easily to the water when heating, and insoluble salt, which retained in the plant when heating (Faboya and Aku, 1996). However, the increment of mineral content might occur after the breaking down of plant tissue which increased the mineral extractability. The heat applied degraded the antinutrient hindered the availability of minerals, causing minerals to be found in the cooked medium (Oulai et al. 2013).

\subsection{Antioxidant content}

The highest antioxidant extraction yield was obtained from raw lotus rhizome (4.03\%), followed by steamed (3.29\%), boiled (2.23\%) and deep-fried (1.19\%) lotus rhizome (Table 3 ). A similar trend was reported by Sultana et al. (2008) on peas, carrot, spinach and white turnip. The antioxidant extraction yield of raw lotus rhizome was in agreement with Yang et al. (2007) who reported that the extract yield was ranged from 4 to $5 \%$ when using methanol as solvent. Contrastingly, the antioxidant extraction yield of lotus rhizome in $\mathrm{Wu}$ et al. (2011) and Zhao et al. (2014) studies were $10.70 \%$ and 5.30 to $6.84 \%$, respectively. Soil nature and agroclimatic condition caused different bioavailability of extractable components in plant tissue and hence contributed to the distinct values of extract yield of antioxidant (Hsu et al., 2006).

Total phenolic content (TPC) of raw lotus rhizome (50.66 mg GAE/g) was higher compared to the cooked sample of lotus rhizomes (11.96 - $43.80 \mathrm{mg}$ GAE/g). This finding is in agreement with Zhao et al. (2014) who found the TPC of lotus rhizome in their studies ranged from 31.63 to $70.01 \mathrm{mg} \mathrm{GAE} / \mathrm{g}$. Contrastingly, Wu et al. (2011) reported a lower result with $16.14 \mathrm{mg} \mathrm{GAE} / \mathrm{g}$ of TPC in the raw lotus rhizome. The variation in the TPC was contributed by the distinct environmental and geological conditions of planting region as reported by Sultana et al. (2008). This is supported by Podsedek (2005) who stated that the polyphenols content for vegetable was varied due to factors such as varieties, climatic conditions, cultural practices, maturity at harvest

Table 3. Yield of antioxidant extraction, total phenolic content, total flavonoid content, $\mathrm{IC}_{50}$ values of DPPH and ABTS radical scavenging activity for raw and cooked lotus (Nelumbo nucifera) rhizome.

\begin{tabular}{cccccc}
\hline Lotus rhizome & $\begin{array}{c}\text { Antioxidant } \\
\text { extraction yield }(\%)\end{array}$ & $\begin{array}{c}\text { Total phenolic content } \\
(\mathrm{mg} \mathrm{GAE} / \mathrm{g} \text { DE })\end{array}$ & $\begin{array}{c}\text { Total flavonoid } \\
\text { content } \\
(\mathrm{mg} \mathrm{CE} / \mathrm{g} \mathrm{CE})\end{array}$ & $\begin{array}{c}\mathrm{IC}_{50} \text { values of DPPH } \\
\text { radical scavenging } \\
\text { activity }(\mu \mathrm{g})\end{array}$ & $\begin{array}{c}\text { IC } \\
\text { ro values of ABTS } \\
\text { radical scavenging } \\
\text { activity }(\mu \mathrm{g})\end{array}$ \\
\hline Raw & $4.03 \pm 0.11^{\mathrm{a}}$ & $50.66 \pm 4.49^{\mathrm{a}}$ & $11.98 \pm 0.38^{\mathrm{a}}$ & 1027 & 495 \\
Steamed & $3.29 \pm 0.13^{\mathrm{b}}$ & $43.80 \pm 2.94^{\mathrm{a}}$ & $10.65 \pm 0.65^{\mathrm{b}}$ & 1186 & 569 \\
Boiled & $2.23 \pm 0.14^{\mathrm{a}}$ & $20.78 \pm 1.70^{\mathrm{b}}$ & $5.13 \pm 0.39^{\mathrm{c}}$ & 1468 & 694 \\
Deep fried & $1.19 \pm 0.03^{\mathrm{a}}$ & $11.96 \pm 0.85^{\mathrm{c}}$ & $2.54 \pm 0.13^{\mathrm{d}}$ & 1705 & 799 \\
\hline
\end{tabular}

Mean $\pm \mathrm{SD}, \mathrm{n}=3$. Values with different superscript letters in the same column are significantly different at $\mathrm{p}<0.05$ 
and storage conditions. Furthermore, boiling and deepfrying decreased the amount of TPC of lotus rhizome which was $20.78 \mathrm{mg} \mathrm{GAE} / \mathrm{g}$ and $11.96 \mathrm{mg} \mathrm{GAE} / \mathrm{g}$, respectively. Boiling contributed to the loss of antioxidant content in vegetable due to leaching out of phenolic compounds into boiling water (Sultana et al., 2008; Hwang et al., 2012; Sengul et al., 2014). Meanwhile, high heat applied during frying would lose most phenolic content compared to other cooking methods, i.e. which caused thermal decomposition of the phenolic compound during frying (Turkmen et al., 2005; Kalkan and Yucecan, 2013).

Total flavonoid content (TFC) of lotus rhizome showed a similar trend with TPC, at which raw lotus rhizome (11.98 $\mathrm{mg} \mathrm{CE} / \mathrm{g} \mathrm{DE}$ ) contained the highest value of TFC, followed by steamed (10.65 mg/g DE), boiled (5.13 $\mathrm{mg} \mathrm{CE} / \mathrm{g} \mathrm{DE}$ ) and deep-fried (2.54 mg CE/g DE) lotus rhizome. Flavonoid compound which is soluble in water could leach out during boiling (Bembem and Sadana, 2012). Thus, boiled vegetable had a lower TFC than steamed samples. The TFC of raw lotus rhizome in the present study was in agreement with Zhao et al. (2014) where the TFC in the lotus rhizome ranged from 7.33 to $13.21 \mathrm{mg} \mathrm{CE} / \mathrm{g} \mathrm{DE}$.

\subsection{Antioxidant activity}

Inhibitory concentration $\left(\mathrm{IC}_{50}\right)$ values of $\mathrm{DPPH}$ $(1027 \mu \mathrm{g})$ and ABTS $(495 \mu \mathrm{g})$ assay for raw lotus rhizome were the lowest among all samples (Table 3 ). The lowest $\mathrm{IC}_{50}$ value indicated the highest antiradical activity (Leong et al., 2012). Thus, the raw lotus rhizome contained the highest antioxidant activity compared to the cooked samples. Meanwhile, Wu et al. (2011) reported that the $\mathrm{IC}_{50}$ value of $\mathrm{DPPH}$ and ABTS assay for the lotus rhizome extract in their studies were 458.58 $\mu \mathrm{g}$ and $4917.51 \mu \mathrm{g}$, respectively. Yang et al. (2007) suggested that the extracting solvent used affected the antioxidant activity of plant extract. The solvent methanol used in the present study was found to have higher antioxidant extraction yield and hence higher antioxidant activity compared to the petroleum ether used by Wu et al. (2011). In addition, the growing region also influenced the antioxidant content and activity for lotus rhizome extract (Zhao et al., 2014).

The $\mathrm{IC}_{50}$ value for ABTS assay of lotus rhizome in the present study was lower than of DPPH due to the different reaction of ABTS assay and DPPH assay. This is in accordance with Al-Laith et al. (2015) findings on three wild medical plants (Aizoon canariense, Asphodelus tenuifolius and Emex spinosus). For instances, ABTS cation radical could react with hydrophilic and lipophilic antioxidant while DPPH radical can only react with hydrophilic antioxidant
(Boligon et al., 2014).

Zhang and Hamauzu (2004) reported that cooking reduced the antioxidant components and activity of broccoli. In the present study, the $\mathrm{IC}_{50}$ value of $\mathrm{DPPH}$ assay for steamed, boiled and deep-fried lotus rhizome were $1186 \mu \mathrm{g}, 1468 \mu \mathrm{g}$ and $1705 \mu \mathrm{g}$, respectively; while of ABTS assay were $569 \mu \mathrm{g}, 694 \mu \mathrm{g}$ and $799 \mu \mathrm{g}$, respectively (Table 3 ). The steaming method caused the least loss of antioxidant activity, followed by boiling in both DPPH and ABTS assay. This is due to polyphenols compound could dissolve in boiled water, thus boiling caused a higher reduction in antioxidant activity in vegetables compared to steaming (Hwang et al., 2012; Sengul et al., 2014). Meanwhile, Kalkan and Yucecan (2013) reported that frying caused the highest loss of antioxidant activity in vegetables. Zhang et al. (2011) suggested that long term exposure to the high temperature degraded the antioxidant compound in bamboo shoot.

\section{Conclusion}

Methods of cooking affect the nutritional composition and antioxidant properties of lotus (Nelumbo nucifera) rhizome. Boiling and deep-frying brought prominent change on the moisture, ash, crude fat, crude protein, crude fibre and carbohydrate content of lotus rhizome whereas steaming brought only a small change of proximate composition when compared to raw lotus rhizome. In addition, steamed lotus rhizome caused the lowest loss of vitamin $\mathrm{C}$ and minerals $(\mathrm{K}, \mathrm{Na}, \mathrm{P}, \mathrm{Mg}$, $\mathrm{Fe}, \mathrm{Zn}, \mathrm{Cu}, \mathrm{Ca}$ and $\mathrm{Mn}$ ) while boiling gave the highest loss of vitamin $\mathrm{C}$ and deep-frying gave the highest loss of most of the minerals in the lotus rhizome. Deep frying caused the significant degradation of antioxidant properties, followed by boiling and steaming. Thus, deep -frying is not recommended for healthy preparation as it increased the fat content significantly in the final product and contributed to a high loss of moisture, vitamin C, minerals and antioxidant properties of lotus rhizome. Overall, steaming is considered as the best cooking methods for lotus rhizome as it retained proximate composition, vitamin $\mathrm{C}$, minerals, TPC, TFC, and antioxidant activity better than boiling and deep-frying.

\section{Conflict of Interest}

The authors declare no conflict of interest.

\section{Acknowledgments}

Authors would like to thank the Faculty of Fisheries and Food Science, Universiti Malaysia Terengganu for the funding and the laboratory staff for their technical assistance in this study. 


\section{References}

Agunbiade, L.W., Abdulsalam, M. and Olaitan, O.D. (2017). Effects of planting locations on the proximate compositions of Moringa Oleifera leaves. Journal of Applied Science and Environmental Management, 21(2), 331-338. https:// doi.org/10.4314/jasem.v21i2.14

Akpinar-Bayizit, A., Turan, M.A., Yilmaz-Ersan, L. and Taban, N. (2010). Inductively Coupled Plasma Optical- Emission Spectroscopy determination of major and minor elements in vinegar. Notulae Botanicae Horti Agrobotanici Cluj-Napoca, 38(8), 64-68.

Al-Laith, A.A., Alkhuzai, J. and Freije, A. (2015). Assessment of antioxidant activities of three wild medicinal plants from Bahrain. Arabian Journal of Chemistry, 46(8), 1-23. https://doi.org/10.1016/ j.arabjc.2015.03.004

Association of Official Analytical Chemists (AOAC). (2005). Official methods of analysis of Association Official Analytical Chemists International. $16^{\text {th }}$ ed. Rockville, MD: AOAC International.

Bembem, K. and Sadana, B. (2013). Effect of cooking methods on the nutritional composition and antioxidant activity of potato tubers. International Journal of Food and Nutritional Sciences, 2(4), 2630.

Bhardwaj, A. and Modi, K.P. (2016). A review on therapeutic potential of Nelumbo nucifera (Gaertn): The sacred lotus. International Journal of Pharmaceutical Sciences and Research, 7(1), 42-54.

Boligon, A.A., Machado, M.M. and Athayde, M.L. (2014). Technical evaluation of antioxidant activity. Medicinal Chemistry, 4(7), 517-522. https:// doi.org/10.4172/2161-0444.1000188

Bordin, K, Kunitake, M.T., Aracava, K.K. and Trindade, C.S.F. (2013). Changes in food caused by deep fat frying - A review. Archivos latinoamericanos de nutricion, 63(1), 5-13.

Bouchon, P., Aguilera, J.M. and Pyle, D.L. (2003). Structure oil- Absorption relationships during deepfat frying. Journal of Food Science, 68(9), 27112716. https://doi.org/10.1111/j.13652621.2003.tb05793.x

Chinomso, O.V., Ejikeme, O.S., Egbuta, K.C., Eze, N.R. and Chidozie, C.D. (2018). The effect of maturity on the proximate composition of orange. Annals of Food Science and Technology, 19(1), 87-91.

Duya, O.C. (2017). Variation in levels of vitamin A and $\mathrm{C}$ with maturity of Amaranthus hybridus (L) leaves grown in different soil- Types in Kwale country, Kenya. Kenya: Kenyatta University, MSc. Thesis.
Faboya, O.O.P. and Aku, U.U. (1996). Interaction of oxalic acid with divalent metals - calcium, magnesium and zinc - during the cooking of cowpea (Vigna unguiculate). Food Chemistry, 57(3), 365369. https://doi.org/10.1016/0308-8146(95)00190-5

Hsu, B., Coupar, I.M. and Ng, K. (2006). Antioxidant activity of hot water extract from fruit of the Doum palm, Hyphaene thebaica. Food Chemistry, 98(2), 317-328.

j.foodchem.2005.05.077

Hussain, M.I., Hamza, A. and Rashid, M.A. (2016). Estimation of vitamin $\mathrm{C}$ in carrot before cooking and after cooking. Journal of Food and Nutrition Sciences, 4(4), 108-112. https://doi.org/10.11648/ j.jfns.20160404.16

Hwang, G., Shin, Y.J., Lee, S., Lee, J. and Yoo, S.M. (2012). Effects of different cooking methods on the antioxidant properties of red pepper (Capsicum annuum L.). Preventive Nutrition and Food Science, 17, 286-292. https://doi.org/10.3746/ pnf.2012.17.4.286

Igwemmar, N., Kolawole, S. and Imran, I. (2013). Effect of heating on vitamin c content of some selected vegetables. Scientific and Technology Research, 2 (11), 209-212.

Ikanone, C.E.O. and Oyekan, P.O. (2014). Effect of boiling and frying on the total carbohydrate, vitamin $\mathrm{C}$ and mineral contents of Irish (Solanun tuberosum) and sweet (Ipomea batatas) potato tubers. Nigerian Food Journal, 32(2), 33-39. https://doi.org/10.1016/ S0189-7241(15)30115-6

Jongrungruangchok, S., Bunrathep, S. and Songsak, T. (2010). Nutrients and minerals content of eleven different samples of Moringa Oleifera cultivated in Thailand. Journal of Health Research, 24(3), 123127.

Kalkan, I. and Yucecan, S. (2013). Stability of dietary phenolics and antioxidant properties of vegetables depends on cooking methodology. Journal of Marmara University Institute of Health Sciences, 3 (1), S9-S16. https://doi.org/10.5455/ musbed.20130118092619

Kim, J., Choi, I., Shin, W.K. and Kim, Y. (2015). Effects of HPMC (hydroxypropyl methylcellulose) on oil uptake and texture of gluten-free soy donut. $L W T$ Food Science and Technology, 62(1), 620-627. https://doi.org/10.1016/j.1wt.2014.03.039

Kita, A. (2014). The effect of frying on fat uptake and texture of fried potato. European Journal of Lipid Science and Technology, 116(6), 735-740. https:// doi.org/10.1002/ejlt.201300276

Lee, S.K. and Kader, A.A. (2000). Preharvest and postharvest factors influencing vitamin $\mathrm{C}$ content of 
horticultural crops. Postharvest Biology and Technology, 20(3), 207-220. https://doi.org/10.1016/ S0925-5214(00)00133-2

Leong, E.S., Tan, S. and Chang, Y.P. (2012). Antioxidant properties and heavy metal content of lotus plant (Nelumbo nucifera Gaertn) grown in extin mining pond near Kampar Malaysia. Food Science and Technology Research, 18(3), 461-465. https://doi.org/10.3136/fstr.18.461

Li, S., Li, X., Lamikanra, O., Luo, Q., Liu, Z. and Yang, J. (2017). Effect of cooking on physicochemical properties and volatile compounds in lotus root (Nelumbo nucifera Gaertn). Food Chemistry, 216, 316-323.

j.foodchem.2016.08.044

Lola, A. (2009). The effect of boiling on the nutrients and anti-nutrients in two nonconventional vegetables. Pakistan Journal of Nutrition, 8(9), 1430 -1433. https://doi.org/10.3923/pjn.2009.1430.1433

Manjunatha, S. Ravi, N., Negi, P.S., Raju, P.S. and Bawa, A.S. (2012). Kinetics of moisture loss and oil uptake during deep fat frying of Gethi (Dioscorea kamoonensis Kunth) strips. Journal of Food Science and Technology, 51(11), 3061-3071. https:// doi.org/10.1007/s13197-012-0841-6

Mehta, B.M. (2015). Nutritional and toxicological aspects of the chemical changes of food components and nutrients during heating and cooking. In Cheung, P.C.K. and Mehta, B.M. (Eds). Handbook of Food Chemistry, p. 897-936. Heidelberg, Berlin: Springer. https://doi.org/10.1007/978-3-642-36605-5_1

Moro, C.F., Yanekura, M., Kouzuma, Y., Agrawal, G.K. and Rakwal, R. (2013). Lotus- A source of food and medicine: current status and future perspectives in context of the seed proteomics. International Journal of Life Sciences, 7(1), 1-5. https://doi.org/10.3126/ ijls.v7i1.6394

Murniece, I., Karklina, D., Galoburda, R., Santare, D., Skrabule, I. and Costa, H.S. (2011). Nutritional composition of freshly harvested and sored Latvian potato (Solanum tubersum L.) varieties depending on traditional cooking methods. Journal of Food Composition and Analysis, 24(4-5), 699-710. https:// doi.org/10.1016/j.jfca.2010.09.005

Oke, E.K., Idowu, M.A., Sobukola, O.P., Adeyeye, S.A.O. and Akinsola, A.O. (2017). Frying of food: A critical review. Journal of Culinary Science and Technology, 16(2), 1-21. https:// doi.org/10.1080/15428052.2017.1333936

Okibe, F.G., Jubril, B., Paul, E.D., Shallangwa, G.A. and Dallatu, Y.A. (2016). Effect of cooking methods on proximate and mineral composition of fluted pumpkin (Telfairia occidentalis) leaves.
International Journal of Biochemistry Research and Review, 9(2), 1-7. https://doi.org/10.9734/ IJBCRR/2016/21483

Omotosho, O.E., Garuba, R., Ayoade, F. Adebayo, A.H., Adedipe, O.E. and Chinedu, S.N. (2016). Effects of deep- fat frying using canola oil, soya oil and vegetable oil on the proximate, vitamins and mineral contents of unripe plantain (Musa x Paradisiaca). Journal of Applied Sciences, 16(3), 103-107. https:// doi.org/10.3923/jas.2016.103.107

Oulai, S.F., Gonnety, J.T., Faulet, B.M., Dje, K.M., Kouassi-Koffi, J.D., Ahi, A.P. and Kouame, L.P. (2013). Effect of cooking times on the proximate and mineral composition of breadfruit (Artocarpus altilis) grown in Abidjan, Cote D'ivoire. Pakistan Journal of Nutrition, 12(8), 768-774. https:// doi.org/10.3923/pjn.2013.768.774

Pegg, R.B., Landen, W.O.Jr. and Eitenmiller, R.R. (2010). Vitamin analysis. In Nielsen, S.S. (Eds). Food analysis, p. 179-200. New York: Springer. https://doi.org/10.1007/978-1-4419-1478-1_11

Podsedek, A. (2007). Natural antioxidants and antioxidant capacity of brassica vegetables: a review. LWT- Food Science and Technology, 40(1), 1-11. https://doi.org/10.1016/j.lwt.2005.07.023

Pongrac, P., Potisek, M., Fras, A., Likar, M., Budic, B., Myszka, K., Boros, D., Necemer, M., Kelemen, M., Vavpetic, P., Pelicon, P., Vogel-Mikus, K., Regvar, M. and Kreft, I. (2016). Composition of mineral elements and bioactive compounds in Tartary buckwheat and wheat sprouts as affected by natural mineral-rich water. Journal of Cereal Science, 69, 916. https://doi.org/10.1016/j.jcs.2016.02.002

Read, B.B. (1982). Famine foods listed in the Chiu Huang Pen Ts'ao. Giving them identity, nutritional values and notes on their preparation. China: Southern Materials Centre, Inc.

Reid, T., Munyanyi, M. and Mduluza, T. (2016). Effect of cooking and preservation on nutritional and phytochemical composition of the mushroom Amanita zambiana. Food Science and Nutrition, 5 (3), 538-544. https://doi.org/10.1002/fsn3.428

Sengul, M., Yildiz, H. and Kavaz, A. (2014). The effect of cooking on total polyphenolic content and antioxidant activity of selected vegetables. International Journal of Food Properties, 17(3), 481 -490 .

https:// doi.org/10.1080/10942912.2011.619292

Severi, S. Bedogni, G., Manzieri, A.M., Poli, M. and Battistini, N. (1997). Effects of cooking and storage methods on the micronutrient content of foods. European Journal of Cancer Prevention, 6 (Suppl. 
1), S21-S24. https://doi.org/10.1097/00008469199703001-00005

Shad, M., Nawaz, H., Hussain, M. and Yousuf, B. (2011). Proximate composition and functional properties of rhizomes of lotus (Nelumbo nucifera) from Punjab, Pakistan. Pakistan Journal of Botany, 43(2), 895-904.

Shunmugapriya, K. and Kalaiselvan, A. (2017). Influence of domestic cooking methods on proximate and phytochemical composition of garlic. Journal of Pharmacognosy and Phytochemistry, 6 (5), 2706-2709.

Sultana, B., Anwar, F. and Iqbal, S. (2008). Effect of different cooking methods on the antioxidant activity of some vegetables from Pakistan. International Journal of Food Science and Technology, 43(3), 560 -567 . https://doi.org/10.1111/j.13652621.2006.01504.x

Sun, H., Mu, T., Xi, L. and Song, Z. (2014). Effects of domestic cooking methods on polyphenols and antioxidant activity of sweet potato leaves. Journal of Agricultural and Food Chemistry, 62(36), 89828989. https://doi.org/10.1021/jf502328d

Tian, J., Chen, J., Lv, F., Chen, S., Chen, J., Liu, D. and Ye, X. (2016). Domestic cooking methods affect the phytochemical composition and antioxidant activity of purple-fleshed potatoes. Food Chemistry, 1979 (Part B), 1264-1270. https://doi.org/10.1016/ j.foodchem.2015.11.049

Turkmen, N., Sari, F. and Velioglu, S. (2005). The effect of cooking methods on total phenolics and antioxidant activity of selected green vegetables. Food Chemistry, 93(4), 713-718. https:// doi.org/10.1016/j.foodchem.2004.12.038

United States Department of Agriculture (USDA) National Nutrient Database for Standard Reference. (2016). Lotus root, raw. Retrieved on April 6, 2018 from USDA Website: https://ndb.nal.usda.gov/ndb/ foods/show $/ 3004$ ?n1=\%7BQv\%3D1\%

$7 \mathrm{D} \& \mathrm{fgcd}=\& \mathrm{man}=\& 1$ facet $=\&$ count $=\& \max =\&$ sort $=\&$ qlookup $=\&$ offset $=\&$ format $=$ Full\&new $=\&$ measureby $=\& \mathrm{Qv}=1 \& \mathrm{ds}=$ Standard + Reference $\& \mathrm{q}=\& \mathrm{qp}=\& \mathrm{qa}=$ $\& \mathrm{q}=\& \mathrm{q}=\&$ ing

Vora, J.D. and Srinivasan, P. (2015). Biochemical, organoleptic and anti-microbial assessment of lotus stem (Nelumbo nucifera). International Journal of Food and Nutritional Sciences, 4(3), 63-67.

Wang, X. (2014). Preliminary assessment of lotus (Nelumbo nucifera Gaertn) rhizomes: An underutilized aquatic vegetable crop. Alabama: Auburn University. MSc. Thesis.

Wu, Y.B., Zheng, L.J., Yi, J., Wu, J.G., Tan, C.J., Chen, T.Q., Wu, J.Z. and Wong, K.H. (2011). A comparative study on antioxidant activity of ten different parts of Nelumbo nucifera Gaertn. African Journal of Pharmacy and Pharmacology, 5(22), 2454-2461. https://doi.org/10.5897/AJPP11.352

Yang, D., Wang, Q., Ke, L., Jiang, J. and Ying, T. (2007). Antioxidant activities of various extracts of lotus (Nelumbo nucifera Gaertn) rhizome. Asia Pacific Journal of Clinical Nutrition, 16(Suppl. 1), 158-163.

Yi, Y., Sun, J., Xie., J., Min, T., Wang, L-M. and Wang, H-X. (2016) Phenolic Profiles and Antioxidant Activity of Lotus Root Varieties. Molecules, 21(7), 863, 1-12. https://doi.org/10.3390/ molecules21070863

Yodkraisri, W. and Bhat, R. (2012). Quality evaluation of deep-fried chips produced from lotus rhizome. International Food Research Journal, 19(4), 14231427.

Yuan, G.F., Sun, B., Yuan, J. and Wang, Q.M. (2009). Effect of different cooking methods on healthpromoting compounds of broccoli. Journal of Zhejiang University Science B, 10(8), 580-588. https://doi.org/10.1631/jzus.B0920051

Zeng, C. (2013). Effects of different cooking methods on the vitamin $\mathrm{C}$ content of selected vegetables. Nutrition and Food Science, 43(5), 438-443. https:// doi.org/10.1108/NFS-11-2012-0123

Zhang, D. and Hamauzu, Y. (2004). Phenolics, ascorbic acid, carotenoids and antioxidant activity of broccoli and their changes during conventional and microwave cooking. Food Chemistry, 88(4), 503509. https://doi.org/10.1016/j.foodchem.2004.01.065

Zhang, J., Ji, R., Hu, Y., Chen, J. and Ye, X. (2011). Effect of three cooking methods on nutrient components and antioxidant capacities of bamboo shoot (Physllostachys praecox C. D. Chu et C. S. Chao). Journal of Zhejiang University Science B (Biomedical and Biotechnology), 12(9),752-759. https://doi.org/10.1631/jzus.B1000251

Zhao, W., Xie, W. Du, S, Yan, S., Li, J. and Wang, Q. (2016). Changes in physicochemical properties related to the texture of lotus rhizomes subjected to heat blanching and calcium immersion. Food Chemistry, 211, 409-414. https://doi.org/10.1016/ j.foodchem.2016.05.075

Zhao, X., Shen, J., Chang, K.J. and Kim, S.H. (2014). Comparative analysis of antioxidant activity and functional components of the ethanol extract of lotus (Nelumbo nucifera) from various growing regions. Journal of Agricultural and Food Chemistry, 62, 6227-6235. https://doi.org/10.1021/jf501644t 